\title{
Grzegorz Gawron*
}

Uniwersytet Śląski w Katowicach

\section{„DESIGN W TERENIE”- \\ PARTYCYPACJA LOKALNYCH SPOŁECZNOŚCI W PROCESIE REWITALIZACJI}

\begin{abstract}
Już od dawna silne uprzemysłowienie województwa śląskiego przestało być jego atutem, który stanowił o postrzeganiu tego regionu jako dominującego w krajowej gospodarce. Wiele śląskich miast i dzielnic nadal nacechowanych jest wyraźnymi śladami przemysłowej przeszłości, które nierzadko prowadzą do niemal całkowitej ich degradacji. Ta industrialna scheda trudnych procesów restrukturyzacji postawiła przed samorządami poważne wyzwania. Odpowiedzią na nie są poszukiwania nowych rozwiązań i scenariuszy, które wprowadzić mają nową jakość w życie i funkcjonowanie lokalnych społeczności. Jednym z ciekawszych przedsięwzięć w tym zakresie były warsztaty projektowe „Design w terenie!”. Ich wyjątkowość polegała na połączeniu potencjału środowisk kreatywnych regionu (projektantów) oraz mieszkańców wybranych miast i osiedli w celu znalezienia nowych rozwiązań odpowiadających na lokalne potrzeby i problemy.
\end{abstract}

Słowa kluczowe: społeczność lokalna, przestrzeń publiczna, partycypacja, rewitalizacja, design

\section{WPROWADZENIE}

Współczesne procesy urbanizacyjne są silnie zróżnicowane, co można obserwować na każdym poziomie analizy. Zróżnicowanie to uwidacznia się w przypadku porównywania wybranych krajów i regionów, ośrodków miejskich czy pojedynczych osiedli. Mamy tutaj bowiem do czynienia z rozbudowanym kalejdoskopem przemian związanych z rozprzestrzenianiem się miast na nowe tereny; przebudowywaniem i uzupełnianiem istniejącej tkanki; konwersją czasem bardzo dużych fragmentów miast i przydzielaniem im nowych funkcji; działaniami rewitalizacyjnymi i jeszcze wieloma innymi typami aktywności. Ich różnorodność i intensywność początkowo wywoływać mogą wrażenie chaosu i onieśmielenie, jednak przyglądając się im bliżej, można zaobserwować pewne podobieństwa, zestaw cech wspólnych, które pozwalają wyodrębnić dwa, równolegle występujące nurty współczesnych procesów urbanistycznych. Pierwszy z nich nazwany został roboczo przez Romana Ruczyńskiego „nurtem rynkowym”.

* Adres do korespondencji: Grzegorz Gawron, Instytut Socjologii Uniwersytetu Śląskiego w Katowicach; e-mail: grzegorz.gawron@us.edu.pl. 
Nazwa ta wydaje się wyjątkowo trafna, ponieważ nurt ten tworzą rozmaite działania i procesy, które łączy jeden cel: osiągnięcie określonego wyniku ekonomicznego. To wyraźne lub czasem zawoalowane nastawienie na maksymalizację zysków. Próbuje się je osiągnąć głównie w wyniku minimalizowania nakładów, eliminowania wszystkich potencjalnie zbędnych elementów, ale również wychwytywania panujących trendów, chwilowych mód i gustów. W ten sposób mieszkania, biura, obiekty czy przestrzenie traktowane są jak zwyczajne produkty rynkowe podporządkowane rynkowo-marketingowym regułom (Ruczyński 2010).

Drugi z obserwowanych nurtów Ruczyński określił mianem „ratunkowego”. Umiejscawiają się tutaj bowiem działania podejmowane głównie z inicjatywy lokalnych władz będące potencjalną odpowiedzią na zgłaszane lub dostrzegane (a czasem jedynie domniemane) potrzeby lokalnych społeczności. Chodzi o działalność prowadzoną z myślą o ratowaniu przestrzeni miejskich jako środowisk mieszkaniowych. Podejmowane są tutaj różnorodne działania, najczęściej o charakterze rewitalizacyjnym, stawiające sobie za główny cel ratowanie istniejących przestrzeni miejskich, których potencjał został uśpiony na długie lata, lecz może stanowić istotny punkt wyjścia przyszłego rozwoju całego obszaru (Ruczyński 2010).

Wydaje się, że w szczególnej sytuacji są małe i średnie miasta. Postrzegane są one bowiem często jako jednostki o potencjalnie mniejszych możliwościach rozwojowych w porównaniu z dużymi ośrodkami o ambicjach metropolitalnych. Tadeusz Markowski uważa, że rozwój mniejszych miast związany jest bardziej z ich walorami materialnymi niż z potencjałem intelektualnym, a w związku z tym ich oferta marketingowa jest strukturalnie prostsza niż w przypadku dużych miast (Markowski 2006). Jednak mimo pozornie ograniczonych możliwości przestrzenie omawianej grupy miast mają swoją specyfikę, która przy odpowiednio prowadzonej polityce rozwoju może stać się atutem. Owa specyfika związana jest z wolniejszym tempem przekształceń przyczyniającym się do zachowania w przestrzeni dużej liczby elementów świadczących o tożsamości danego miejsca. W przypadku takich ośrodków pojawiającą się szansą może być obserwowany współcześnie renesans społecznej i przestrzennej mikroskali, a więc miejsc i społeczności, które zachowały niepowtarzalność i autentyczność (Jałowiecki i Szczepański 2005). Bezwzględnie konieczne jest jednak dostrzeżenie tego drzemiącego kapitału oraz podjęcie konkretnych działań służących jego wydobyciu i wykorzystaniu do rozwoju danej miejscowości, a przede wszystkim społeczności, dla której jest ona domem.

Tożsamość przestrzeni, mimo że trudna do skwantyfikowania, staje się zatem wartością ekonomiczną. Powyższa prawidłowość w sposób szczególny odnosi się do przestrzeni publicznej, która stanowi rdzeń struktury funkcjonalno-przestrzennej miasta. W mniejszych ośrodkach place, ulice czy parki wciąż pozostają głównym miejscem spotkań i integracji mieszkańców. W ostatnich latach zauważalna jest intensyfikacja wysiłków miejskich włodarzy na rzecz podniesienia jakości tych przestrzeni (Markowski 2002). Oczywiście zainteresowanie to wynika w dużej mierze z możliwości pozyskania lwiej części potrzebnych funduszy z dostępnych środków Unii Europejskiej (Golędzinowska 2010: 114), co daje szanse na projektowanie i realizację przedsięwzięć, dla których ograniczenia finansowe nie stanowią kryterium wpływającego na ich jakość. Ważniejsze wydaje się jednak, widoczne w wielu zrealizowanych już projektach, przesunięcie osi priorytetów w kierunku jednoznacznie zidentyfikowanych potrzeb lokalnych społeczności. To ich zaspokojenie staje się bowiem głównym celem, którego osiagnięcie warunkowane jest współudziałem tych społeczności w kreowaniu pożądanej zmiany. Pomaga w tym również, dostrzegalna coraz częściej, otwartość 
samorządów na współpracę z przedstawicielami różnych środowisk, których zaangażowanie sprzyja rozbudzaniu potencjału partycypacyjnego lokalnych społeczności.

Poniższe rozważania to prezentacja jednego z przykładów takiej współpracy, w którą zaangażowani zostali przedstawiciele sektora kreatywnego - studenci kierunków projektowych śląskich uczelni. Pod okiem ekspertów przez siedem dni mieszkali i pracowali w Radlinie - jednym ze śląskich miast, którego wybrane przestrzenie poddano próbie rewitalizacji. Opisywany przykład to przyczynek do nakreślenia charakterystyki swoistej „użyteczności” designu jako narzędzia, a raczej praktyki działania, służącej pobudzaniu i wykorzystywaniu bezpośredniej partycypacji mieszkańców w kreowaniu, pożądanej przez nich samych, zmiany.

Dlatego skupiono się na przybliżeniu pojęcia przestrzeni publicznej i jej znaczenia dla funkcjonowania miasta, a przede wszystkim mieszkańców będących użytkownikami i kreatorami owej przestrzeni. Starano się przy tym wyeksponować istotę obserwowanej powszechnie restytucji lokalnych społeczności, nabierających stopniowo odwagi w eksponowaniu własnych potrzeb i oczekiwań ich zaspokojenia względem lokalnych włodarzy. Istotą partycypacji jest bowiem umiejętne wykorzystanie szeroko rozumianego „kapitału” drzemiącego w lokalnych społecznościach - ludziach, dla których otaczająca ich przestrzeń jest jednym z istotnych wskaźników (punktów odniesienia) w kształtowaniu własnej (indywidualnej i grupowej) tożsamości.

\section{DLACZEGO MIEJSKIE PRZESTRZENIE PUBLICZNE?}

W całej historii uznawane one były za zasadnicze i w pełni esencjonalne części każdego miasta. Na tle życia miejskiego przestrzenie publiczne stale odzwierciedlają złożoność panujących kontekstów kulturowych, społecznych i gospodarczych. Bez względu na czas i sytuację odgrywają szczególną rolę w życiu społecznym jako pamiętne, dostępne lub znaczące miejsca (Rasouli 2013: 4).

Tradycyjnie przestrzenie publiczne miasta obejmują jego centrum z siecią ulic, placów i skwerów oraz ulokowanych tam elementów (budowli, pomników, ławek itp.) określających ich specyfikę. To przestrzenie sprzyjające wszelkim formom kontaktów i praktyk społecznych - od codziennych po odświętne (Wallis 1979). Przyjmuje się zatem, że należą do nich obszary miasta dostępne dla wszystkich, w których może się znaleźć każda jednostka i grupa społeczna, dlatego też stanowią istotny warunek istnienia i rozwoju miasta. Są to przestrzenie, w których zaspokajane są potrzeby różnych użytkowników oraz realizują się wspólne interesy określonej społeczności. W samym ich pojęciu kryje się zatem bogactwo znaczeń i odniesień do wielu kontekstów: rozwoju indywidualnego i obywatelskiego, komunikacji międzyludzkiej, kultury, polityki, ekonomii czy środowiska zbudowanego (Dymnicka 2013: 12).

Dlatego jednym z najważniejszych kryteriów decydujących o publicznym charakterze danej przestrzeni jest jej dostępność, mająca kilka wymiarów: fizyczny, związany z aktywnością, dostępem do informacji i zasobów. Zatem przestrzeń publiczna to przestrzeń uwspólnienia, w obrębie której każdy członek wspólnoty podziela pewne reguły dostępu do fizycznej lub metaforycznie pojmowanej sfery. Innymi słowy, cokolwiek stanie się w tej przestrzeni, dotyczy wszystkich. Stąd z jednej strony nabiera ona cech „dobra wspólnego”, a z drugiej - staje się przedmiotem zbiorowej kontroli (Dymnicka 2013: 58). 
Przestrzenie publiczne miast są więc miejscami spotkań, zgromadzeń czy swobodnej ekspresji równych grup społecznych (Lorens 2005: 104). Pamiętać jednak należy o całym wachlarzu możliwych form aktywności ludzkiej w przestrzeni publicznej. Jan Gehl wymienia tu takie elementy, jak: działania konieczne - „funkcjonalne” (czyli większość codziennych czynności, na przykład przejazd do pracy, szkoły), działania możliwe - „rekreacyjne” (takie, które są dokonywane, jeśli jest wola, aby ich dokonać, a także sposobność ku temu, czas i miejsce - jak np. spacer, opalanie się itp.) oraz działania społeczne - ,wynikowe” (wszystkie zależne od obecności innych w przestrzeni publicznej, na przykład zabawy dzieci, spotkania ze znajomymi itp.). Uważa on, że charakter działań społecznych jest bardzo zróżnicowany i zależy kontekstu, w którym się one dzieją. Aktywności społeczne często zachodzą bowiem spontanicznie jako bezpośrednia konsekwencja poruszania się i bytności ludzi w tej samej przestrzeni. Oznacza to, że ich występowanie w dużym stopniu zależy od przystosowania przestrzeni publicznej do odbywania tych różnorodnych aktywności (Lorens 2010a: 62-63).

Dlatego, jak pisze Krzysztof Frysztacki, charakteryzując przestrzenie publiczne, należy zwrócić szczególną uwagę na ich dwa aspekty: materialny i społeczny. W tym pierwszym powinny być one stosunkowo otwarte i w sposób nieskrępowany służyć tym, którzy chcą je zajmować czy wykorzystywać. Winny być również autentyczne, to znaczy pozostawać w zgodzie ze społecznymi oczekiwaniami i upodobaniami, rozwijać się i modyfikować w sposób pozwalający na pewną naturalność, odzwierciedlać swym wyposażeniem i możliwościami coś, co określilibyśmy jako aksjologię społeczności miejskiej. Wreszcie winny być to przestrzenie możliwe do ogarnięcia: wzrokiem, spacerem, możliwością skupiania się ludzi, których rozpoznajemy i z którymi ewentualnie się identyfikujemy. Mają to być zatem przestrzenie „dobre”. Z drugiej strony, w aspekcie społecznym, mogą być one definiowane jako publiczne przez tych, którzy ową publiczność tworzą. Co za tym idzie, muszą być społecznie akceptowane, by wreszcie dawać pewne poczucie bezpieczeństwa w szerokim i złożonym sensie tego określenia. W tej perspektywie przestrzenie te mogą być zatem określane jako „przyjazne” (Frysztacki 2005: 152-153).

Przestrzenie publiczne, będące elementami struktury miasta, poddawane są tym samym prawom i procesom, które rządzą przekształceniami formy miejskiej i wzoru miejskiego życia. Są one jednak elementami struktury miasta najbardziej wrażliwymi na te zjawiska kulturowe, które modyfikująjego życie i formę przestrzenną. Oznacza to, że możemy mówić o przestrzeniach publicznych jako o przestrzeniach kultury. Wśród tych zjawisk wymieniane są między innymi przeobrażenia cywilizacyjne, ale także interakcje pomiędzy samymi przestrzeniami a otaczająca je tkanką miejską (Zuziak 2002; Lorens 2010a). Dlatego publiczne przestrzenie miejskie mają wielowymiarową wartość społeczną (Varena i Tiesdell 2010).

Jednocześnie, jak już wspomniano, są one obecnie poddawane procesom gwałtowanych zmian, często budzących niepokój o ich konsekwencje. Stanowią bardzo istotny składnik struktury każdego miasta, ponieważ w ich obszarze zróżnicowana aktywność i model współżycia mieszkańców manifestują się najsilniej. Współdecydują one także o specyfice miasta jako tworu kultury i przestrzennych ram, w których kultura powstała i rozwijała się (Kochanowski 2002).

Tym samym na pierwszy plan wysunęła się kolejna potrzeba społeczna - potrzeba stymulacji. Jest ona związana z potrzebą kontaktu z innymi ludźmi. W przeciwieństwie do oglądania budynków, przebywanie wśród ludzi oferuje całe bogactwo wrażeń zmysłowych. 
Dlatego też takie znaczenie przypisuje się obecnie przestrzeniom publicznym - wynika ono z dążenia do ożywienia miast i uczynienia ich atrakcyjnymi. Albowiem żywe miasta to takie, w których mogą zachodzić różnorakie interakcje pomiędzy ludźmi (Lorens 2010b: 7).

Wielu badaczy zgadza się ze stwierdzeniem, że zrozumienie relacji między ludźmi i przestrzenią, w której żyją, jest niezbędnym elementem urbanistyki. Ludzie i stworzone (przekształcone) przez nich środowiska są bowiem ściśle ze sobą powiązani. Trudne jest zatem zrozumienie znaczenia wybranej przestrzeni (miejsca) bez znajomości kontekstu społecznego, który został jej nadany. Ludzie i ich otoczenie są interaktywnie powiązani i wpływają na siebie wzajemnie. Dlatego w wyniku tworzenia określonego zabudowanego środowiska projektanci miejscy wywołują określone wzory użytkowania, a tym samym życia społecznego. Cechy fizyczne nie sąjednak wyłącznym ani niekoniecznie dominującym źródłem wpływu na wzorce aktywności, choć to, co ludzie są w stanie zrobić, jest ograniczone przez przewidziane dla nich możliwości środowiskowe. Dlatego wzór aktywności zależy nie tylko od sytuacji, ale także od kontekstu społecznego i kulturowego (Carmona 2010). Tak więc, podczas gdy projektanci tworzą potencjalne środowisko, ludzie tworzą środowisko efektywne. Relacje między ludźmi i ich środowiskiem winny więc być postrzegane jako niekończący się proces dwustronnej stymulacji, której efektów doszukiwać się można w jakości danej przestrzeni oraz rozwijających się w niej relacjach społecznych (Rasouli 2013).

Współcześnie kształtowanie przestrzeni publicznych jest więc zadaniem złożonym i wielowymiarowym. Motorem tych działań powinna być inicjatywa lokalna. Współudział mieszkańców i użytkowników oraz kontrola społeczna nad poczynaniami władz i zawodowych projektantów nie jest oczywiście gwarantem osiągnięcia sukcesu, jednak wiele przykładów potwierdza, iż partycypacja ta istotnie pomnaża prawdopodobieństwo realizacji zakładanych celów (Kosiński 2013).

\section{RESTYTUCJA I PARTYCYPACJA LOKALNYCH SPOŁECZNOŚCI}

Wśród opracowywanych i wdrażanych w ostatnich latach planów przestrzennych i rozwojowych polskich miast dominuje podejście „,projektowe” opierające się na ścisłym podziale zadań i kompetencji. Przyczyną każdego działania jest potrzeba realizacji projektu (nowego stadionu, budynku, obwodnicy itp.). Należy oczywiście zaznaczyć, że tak jak wiele innych, również i te wzorce czerpiemy z Zachodu. Specjaliści przygotowują alternatywne rozwiązania i poddają je „społecznej dyskusji”, podczas której społeczność może się na ich temat wypowiedzieć i potencjalnie wpłynąć na wybór jednego z rozwiązań. W czym więc tkwi problem? W tym, że w większości przypadków takie działania nie wynikają z rzeczywistego, społecznego zapotrzebowania, zdefiniowanego i wyartykułowanego przez lokalną społeczność, a przestrzeń publiczna nie stanowi w nich punktu wyjścia. Jest to typowe podejście „odgórne”, pomijające ideę i potrzebę działań „oddolnych”. Wyróżnić tutaj nawet można cztery czynniki składające się na ten przyjmowany schemat przekształcania przestrzeni publicznych:

- zbiorowość lokalna nie jest uwzględniana w procesie planowania; w rezultacie jej wkład jest spóźniony, pojawia się „po fakcie”: kiedy pomysły i rozwiązania już dojrzały, a mieszkańcy mają na nie jedynie zareagować; 
- siła społeczności lokalnej, polegająca na znajomości lokalnych problemów, nie jest wykorzystywana w krytycznym momencie, a więc na samym początku prac koncepcyjnych; zamiast tego mieszkańcy są proszeni o ocenę gotowej propozycji planu, co nawet ekspertowi może przysporzyć trudności; pokazując naraz cały, opracowany już materiał, wymaga się od mieszkańców podjęcia trudnych decyzji i przyjęcia współodpowiedzialności;

- niekorzystny bilans czasu; projekty pochłaniają go wiele, zanim zaowocują, natomiast drobniejsze ,poprawki” mogą być realizowane znacznie szybciej, a do tego są często mniej kosztowne;

- brak porozumienia agend miejskich; wiele z nich (jak na przykład wydziały transportu, planowania i zieleni) ma do czynienia z różnymi problemami społeczności lokalnej - ale zamiast współpracować, pracują oddzielnie, nie tworząc projektów całościowych, wielowymiarowych, a tym samym bardziej efektywnych (Jak przetworzyć miejsce... 2013).

Tymczasem liczne badania wskazują, że to właśnie dzięki zaangażowaniu w sprawy społeczności lokalnej poszczególne jednostki są w stanie bezpośrednio wpływać na dynamikę i kierunek jej rozwoju. Ewolucja roli samorządu lokalnego prowadzi do zaangażowania mieszkańców w zarządzanie sprawami publicznymi i na nim polega. Emocjonalne więzi łączące członków społeczności lokalnej powstają w obliczu konieczności rozwiązywania wspólnych problemów. Siła tych więzi wynika z faktu, że większość potrzeb jednostki może zostać zaspokojona jedynie na poziomie społeczności lokalnych. W rezultacie stają się oni (ludzie) podmiotami społecznej samoorganizacji i integracji oraz rozwoju wspólnej lokalnej świadomości, a w konsekwencji współkreują rozwój swojej wspólnoty (Hausner 1999).

Już samo pojęcie partycypacji społecznej oznacza udział obywateli w zarządzaniu sprawami społeczności, której są członkami. W szerokim rozumieniu partycypacja społeczna jest podstawą społeczeństwa obywatelskiego, którego członkowie dobrowolnie biorą udział w publicznej działalności. W węższym rozumieniu pojęcie to oznacza partnerstwo publiczno-prawne samorządu gminnego i mieszkańców służące podejmowaniu działań na rzecz rozwoju lokalnego (Hausner 1999: 41).

Zapewnienie udziału społecznego i dostępu do informacji jest jednym z priorytetów polityki Unii Europejskiej i zostało uregulowane między innymi w Konwencji o dostęie do informacji, udziale społeczeństwa w podejmowaniu decyzji oraz dostępie do sprawiedliwości z 1998 roku, ratyfikowanej przez Polskę w 2001 roku (Dz.U. z 2003 r. Nr 78, poz. 706).

Warto również wspomnieć o określonych przez OECD trzech poziomach interakcji między władzą publiczną (samorządową) i obywatelami (OECD 2001):

- informowanie - dostarczanie zainteresowanym stronom informacji na tematy publiczne,

- doradztwo - otrzymanie informacji zwrotnej od obywateli w zakresie podejmowanych kwestii,

- aktywne uczestnictwo - zaangażowanie obywateli w proces tworzenia polityki i podejmowania decyzji (Hałat 2010: 59-60).

Tadeusz Markowski (1999) zauważa, że zdolność i chęć samorządów do współpracy z lokalnymi instytucjami, organizacjami i społecznościami umożliwia tworzenie partnerskich relacji postrzeganych współcześnie jako istotne przejawy profesjonalnego zarządzania (Kożuch 2003; Hałat 2010). 
Potrzebne są zatem dość radykalne zmiany obecnego sposobu planowania miejscowego. Powszechnym standardem powinny stać się działania i narzędzia opierające się na kontakcie i rzeczywistej współpracy ze społecznością. Takie podejście daje bowiem szanse profesjonalistom na wydobycie idei tkwiących w społeczności - poznanie jej punktu widzenia, rzeczywistych problemów, ale co jeszcze ważniejsze, pomysłów na zmiany miejscowych przestrzeni publicznych. Wszystkie uzyskane w ten sposób informacje są projekcją społecznej wizji i nadziei na przyszłość. Rolą profesjonalistów jest wtedy realizacja wizji wykreowanej przez lokalną wspólnotę (Jak przetworzyć miejsce... 2013).

Tej restytucji „małych ojczyzn” towarzyszy swoiste odkrywanie pamięci o miejscach i ludziach je zamieszkujących. Ów awans pamięci wiąże się z jej demokratyzacją, co prowadzi nas w stronę decentralizacji modelu kultury. Obecnie to nie państwo ze swoją scentralizowaną administracją i generalną orientacją na centrum ma stanowić o tożsamościach zbiorowości, ale one same niezależnie od nakazów władzy odkrywają swoją odrębność i swoistość. Tendencje te prowadzą do odkrywania, renesansu, a także wskrzeszania owego genius loci - „ducha miejsca” (Lorens 2010a: 13). Służy temu często rewitalizacja wybranych terenów dająca ujście lokalnym potrzebom i ambicjom tworzenia miejsc dla ludzi.

\section{DESIGN I REWITALIZACJA}

Partycypacja społeczna to niezbędny element procesu rewitalizacji. Jej istota zawarta jest już w samej definicji rewitalizacji, która powinna być rozumiana jako proces społecznych i skoordynowanych inwestycji przekształcania zdegradowanych przestrzeni miejskich, działań prowadzonych wspólnie przez władze lokalne, społeczność lokalną i innych zainteresowanych uczestników (Hałat 2010: 59).

Jako proces rewitalizacja (dosłownie: przywrócenie do życia) powinna być bowiem dobrze zaplanowaną i kompleksową agregacją przemian przestrzennych, społecznych i ekonomicznych, których celem jest nie tyle wyprowadzenie określonego terenu ze stanu kryzysowego, ile przede wszystkim pobudzenie do rozwoju wywołującego uwidaczniającą się z czasem poprawę jakości życia lokalnych społeczności. Niestety programy rewitalizacyjne powszechnie utożsamiane są z odnową zaniedbanych dzielnic miejskich i poprzemysłowych. Tymczasem ostatecznym celem rewitalizacji nie jest wprowadzenie nowego ładu przestrzennego na danym terenie, lecz poprawa jakości życia ludzi zamieszkujących zdegradowane obszary (Pilch 2004). Niedopuszczalne jest zatem ograniczanie pojmowania procesu rewitalizacji do tak zwanych projektów infrastrukturalnych, związanych głównie z inwestycjami budowlanymi i renowacyjnymi. Obejmować ona powinna również, a raczej przede wszystkim, szereg „miękkich” działań, nastawionych na odbudowę i rozwój kapitału ludzkiego (Pilch 2004). Wszelkie zmiany fizycznej przestrzeni miejskiej traktować należy jedynie jako narzędzia, a nie cele rewitalizacji. Jest więc to proces obejmujący kilka wzajemnie powiązanych i często silnie współzależnych sfer: gospodarczą (przedsiębiorczość, powiązania i funkcje ekonomiczne, rynek pracy), społeczną (zasoby ludzkie, struktura społeczna, aktywność społeczna, zachowania, tradycje), materialno-techniczną (budynki, budowle, infrastruktura) i przestrzenną (jakość zagospodarowania) (Gawron i Rojek-Adamek 2012a: 124). 
Biorąc pod uwagę główną oś problemową podejmowanych tutaj rozważań, należy w tym miejscu zadać pytanie: ,jaka jest rola designu w tworzeniu miejsca?”. Z tradycyjnym procesem projektowym kontrastuje podejście wynikające ze skoncentrowania uwagi na cechach miejsca, które wymaga rozszerzenia postrzegania poszczególnych podmiotów poza ramy stereotypowego prymatu estetyki designu. Tworzenie miejsca w większym stopniu uzależnione jest od efektywnego zarządzania niż projektowanie i wymaga zaangażowania przedstawicieli wielu różnych dyscyplin, z powodu niezwykłej złożoności problemów, które muszą zostać rozwiązane (Jak przetworzyć miejsce... 2013: 44).

\section{DESIGN W SŁUŻBIE MIASTU}

Design jako jeden z sektorów kreatywnych wpisuje się doskonale w działania służące kształtowaniu miejskich przestrzeni, w tym również projektów rewitalizacyjnych. Projektanci bowiem w wyniku wielowymiarowej działalności w sposób bezpośredni i pośredni przyczyniają się do poprawy jakości miejskiego życia - począwszy od dobrze zaprojektowanych przedmiotów, po sprawnie działającą komunikację i rozwiązania w zakresie zarządzania. Współczesne rozumienie designu pokazuje możliwe ścieżki jego wykorzystania, wśród których za najważniejsze postrzegane są:

- projektowanie produktów - dzięki nim rozpoznajemy firmę i kształtujemy swoje oceny,

- projektowanie komunikacji - odnoszące się do wszystkich elementów komunikacji wizualnej - od symbolu i identyfikacji po opakowania, reklamę, instrukcje czy wytyczne,

- projektowanie informacji i interfejsów - od interfejsów internetowych po interfejsy urządzeń, od oznakowania przestrzeni miejskiej po sposób zarządzania kontami w banku,

- projektowanie otoczenia - od środowiska handlowego do salonów wystawienniczych, od wystaw do miejsc pracy, od architektury biurowej do mieszkalnej,

- projektowanie usług - od procesów bankowych po restauracje, od szpitali po urzędy, od hoteli po firmy przewozowe (Lockwood 2010).

W ostatnich latach coraz częściej uwidacznia się potrzeba angażowania projektantów (designerów) w działania związane z szeroko pojętym rozwojem społecznym. Jednym z poziomów, na których realizować się mogą przejawy tej działalności, jest rozwój jednostek terytorialnych (gmin, województw). Ich działalność wykracza poza przestrzeń prywatną i ujawnia się w przestrzeni publicznej. Zakres współpracy na tym poziomie dotyczyć więc może między innymi:

- podejmowania przez miasto/powiat/gminę działań podnoszących estetykę przestrzeni publicznej, jej walorów architektonicznych, funkcjonalności oraz bezpieczeństwa,

- uczestnictwa w działaniach o charakterze rewitalizacyjnym,

- prowadzenia działań promujących miasto/gminę/powiat,

- prowadzenia działań tworzących identyfikację powiatu/gminy,

- dobrej komunikacji administracji samorządowej ze społecznością lokalną i biznesem. 
Rysuje się w ten sposób szeroki obszar współpracy samorządów lokalnych i projektantów stanowiący odpowiedź na stopniowo dostrzegane zapotrzebowanie w zakresie działań służących szeroko pojmowanemu rozwojowi na poziomie lokalnym i regionalnym (Gawron i Rojek-Adamek 2012b: 260).

W opiniach wielu praktyków i obserwatorów, design jest niezbędnym elementem kreacji przestrzeni publicznych, ale najlepsze przestrzenie rodzą się przede wszystkim ze zrozumienia, jak będą one użytkowane przez społeczeństwo. Poleganie na talentach i wizji lokalnej wspólnoty nie oznacza wszelako rezygnacji z mocnych działań projektowych - przeciwnie, często proces partycypacyjny buduje siłę projektu (Jak przetworzyć miejsce... 2013: 67). Można bowiem mówić wówczas o projektowaniu odpowiedzialnym, które angażuje społeczność lokalną (projektowanie z ludźmi, a nie tylko dla ludzi). Konieczne jest jednak wcześniejsze przyjęcie i uznanie założenia, że to mieszkańcy są najlepiej zorientowani w kwestii użytkowania danej przestrzeni (określonego terenu). Dlatego ich roli w procesie projektowym nie można pominąć i niczym zastąpić. Dopiero bowiem odpowiednie włączenie ich wiedzy, doświadczenia i aspiracji pozwala mówić o projekcie, iż jest osadzony w kontekście. Kontekst ten staje się wówczas pretekstem i punktem odniesienia dla odpowiedzialnego projektowania na każdym etapie: diagnozy, formułowania alternatywnych koncepcji, ich weryfikowania i oceny. Jest również podstawą, na której opiera się końcowe rozwiązanie. Ludzie, z którymi projektanci pracują, poznają wtedy „swoje miejsca” szczegółowo i z innej perspektywy, uczą się odpowiedzialności za przestrzeń, którą zamieszkują i regularnie lub okazjonalnie wykorzystują. Będąc współtwórcami projektu, mogą uznać go za własny, a także utożsamiać się z efektami jego realizacji. Taka identyfikacja wpływa nie tylko na sukces projektowania, ale również przesądza o trwałości jego wyników. Pozwala bowiem poczuć ludziom, że mają wpływ na swoje otoczenie, i wyrywa ich z marazmu. Sprzyja pojawieniu się nowych liderów życia społecznego oraz aktywizacji obecnych (Jaworski 2013).

Pojęcie wspólnej przestrzeni nie może się bowiem urzeczywistnić, jeśli mieszkańcy nie chcą mieć do niej tytułu jako obywatele, którym na czymś zależy, wspólnie do czegoś dążą lub na coś się nie zgadzają. Wspólne dobro wymaga wspólnego działania i współodpowiedzialności. Także w zakresie aktywnego i zintegrowanego zarządzania problemami środowiskowymi (Dymnicka i Rozwadowski 2009: 47). Dlatego rolę profesjonalistów (w tym także projektantów) zaangażowanych w kreowanie użytecznych, lubianych miejsc należy określić jako pomocniczą wobec lokalnych społeczności. Profesjonaliści, podobnie jak organizacje pożytku publicznego i urzędy, są zaangażowani w proces polegający na wdrożeniu i realizacji społecznej wizji. W większości przypadków oznacza to, że profesjonaliści i urzędnicy, dotąd pełniący funkcje ekspertów, będą musieli zaakceptować zmianę swojej pozycji względem społeczności - z przewodniej na wspierającą (Jak przetworzyć miejsce... 2013).

\section{DESIGN W TERENIE}

Za udaną próbę wdrażania takiej wizji w rzeczywistość można uznać warsztaty projektowe „Design w terenie!”, podczas których grupa młodych projektantów miała za zadanie stworzyć koncepcje zagospodarowania i aktywizacji kluczowych miejsc - przestrzeni publicznych 
wybranych śląskich miejscowości. Przedsięwzięcie to było realizowane w ramach wielowymiarowego i wyjątkowego w skali kraju projektu „Design Silesia”. Liderem i inicjatorem całego przedsięwzięcia był Urząd Marszałkowski Województwa Śląskiego, a jego realizacja opierała się na współpracy z czterema partnerami: Akademią Sztuk Pięknych w Katowicach, instytucją kultury Ars Cameralis Silesiae Superioris, Politechniką Śląską w Gliwicach oraz Zamkiem Cieszyn.

Jeden z obszarów zainteresowania w ramach podejmowanych działań dotyczył przestrzeni publicznych. Realizatorzy projektu przyjęli bowiem założenie, że dobra organizacja transportu miejskiego, wysoka jakość, atrakcyjność oraz przede wszystkim funkcjonalność elementów wyposażenia przestrzeni miejskiej, przestrzeni do rekreacji i wypoczynku czy budynków użyteczności publicznej, podnoszą jakość życia mieszkańców. To z kolei może zwiększyć aktywność społeczną i zawodową obywateli, co przekłada się na gospodarczy i kulturalny rozwój regionu. W programie „Design Silesia” przewidziano zatem edukowanie samorządów w tym zakresie, a więc z jednej strony podkreślenie wagi działań podnoszących jakość przestrzeni publicznej, a z drugiej - uświadomienie, w jaki sposób design może wspierać proces dokonywania zmian w tym obszarze (www.design-silesia.pl).

Jednym z kluczowych zadań były tutaj wspomniane warsztaty terenowe. Studenci kierunków projektowych śląskich uczelni pod okiem ekspertów przez siedem dni mieszkali i pracowali w wybranej gminie, starając się jak najlepiej ją poznać. W procesie projektowym główny nacisk położono na rozwiązania odpowiadające lokalnym potrzebom. Intensywny tydzień warsztatów wypełniały rozmowy z mieszkańcami gminy, dyskusje i wizyty terenowe. W programie warsztatów mieściło się też kilka wykładów otwartych, omawiających różne aspekty związane z przestrzeniami publicznymi. Miały one na celu zainspirowanie uczestników i mieszkańców do odmiennego sposobu myślenia o miejscowości, w której odbywały się warsztaty, oraz do spojrzenia na lokalne wyzwania w szerszej perspektywie. Efektem warsztatów stały się konkretne koncepcje i rozwiązania projektowe powstające każdorazowo dzięki silnej partycypacji mieszkańców uczestniczących we wszystkich etapach podejmowanych prac (Gdowicz i Więckowska 2013: 12).

W ramach całego przedsięwzięcia „Design Silesia” zorganizowane zostały trzy edycje opisanych warsztatów w: Mstowie, Bytomiu-Bobrku oraz Radlinie. Każdorazowo wybór konkretnej gminy odbywał się na podstawie nadsyłanych zgłoszeń, w których włodarze poszczególnych miejscowości mieli wskazać potrzebę realizacji warsztatów na ich terenie oraz przekonać powołane jury do wyjątkowości reprezentowanej jednostki samorządowej.

\section{RADLIN - PRZYGODA Z DESIGNEM}

W tym przypadku przedmiotem warsztatów było XIX-wieczne, ceglane osiedle Kolonia Emma zbudowane obok kopalni Marcel w Radlinie ${ }^{1}$. Osiedle tworzą jednopiętrowe ceglane domy, z których każdy jest wyjątkowy, jednak wspólnie stanowią spójną urbanistyczną

\footnotetext{
1 Niewielkie miasto położone w południowej Polsce, w województwie śląskim, w powiecie wodzisławskim.
} Według danych z 31 grudnia 2013 roku miasto zamieszkiwało 18146 mieszkańców. 
przestrzeń. Kolonia Emma powstała około 115 lat temu z przeznaczeniem do zamieszkania przez pracowników kopalni. Stanowiła wówczas nowoczesny kompleks budynków, wyróżniający się na tle pozostałych części Radlina, służąc przez długie lata swoim mieszkańcom. Jednak po reformie administracyjnej przeprowadzonej w 1975 roku Radlin znalazł się w granicach Wodzisławia, co szczególnie negatywnie odbiło się na dalszym losie ceglanego osiedla, które z niegdysiejszej perełki architektury stało się zapleczem lokali socjalnych. Do pogorszenia sytuacji przyczyniła się, dotycząca również radlińskiej kopalni, restrukturyzacja górnictwa, na skutek której wiele osób zamieszkujących Emmę pozostało bez pracy. W konsekwencji również w obrębie tej niewielkiej społeczności zaczęły pojawiać się problemy identyfikowane jako przejawy stopniowego wykluczenia społecznego, a Emma, która w międzyczasie zmieniła nazwę na Marcel, zyskiwać zaczęła opinię niebezpiecznej dzielnicy. Z perspektywy samorządu przełomowy okazał się rok 1997, kiedy po długich staraniach Radlin znów stał się samodzielnym miastem. Umożliwiło to rozpoczęcie wielu prac remontowych, poprawiania infrastruktury oraz - przede wszystkim - szeroko rozumianej pracy animacyjnej ze społecznością lokalną (Gdowicz i Więckowska 2013: 17).

W tym zakresie jedną z najistotniejszych ról w ostatnich latach, odgrywał projekt Ośrodka Pomocy Społecznej pod nazwą „Nowe Horyzonty. Aktywna integracja mieszkańców Radlina”. Działania, współfinansowane ze środków Europejskiego Funduszu Społecznego, miały zachęcić mieszkańców do aktywności na rzecz lokalnej wspólnoty. Chociaż, opierając się na danych statystycznych dotyczących przestępczości i wykroczeń, można już stwierdzić, że Emma nie wyróżnia się pod tym względem na tle pozostałych dzielnic Radlina, to jednak istotnym problemem pozostaje, wciąż głęboko zakorzenione w świadomości mieszkańców całego miasta i okolic, przeświadczenie, że Emma to „slums”, „getto” czy zapomniana dzielnica (Gdowicz i Więckowska 2013: 23).

Z tymi właśnie mitami chcieli zmierzyć się uczestnicy zorganizowanych warsztatów „Design w terenie!’. Po zapoznaniu się z mieszkańcami i ich problemami zespół projektantów podzielony został na trzy grupy robocze, z których każda zajęła się opracowaniem jednego zagadnienia. W założeniach i praktyce prace opierały się na silnej partycypacji mieszkańców osiedla, władz samorządowych i przedstawicieli miejskich instytucji. Wybrane w tym celu metody i techniki (tj. spacer komentowany, tworzenie map mentalnych, wykłady otwarte, debaty i prezentacje wstępnych koncepcji projektowych), pozwoliły na pełną współpracę projektantów i przedstawicieli osiedlowej społeczności. W rezultacie tygodniowych zmagań wypracowane zostały trzy odrębne koncepcje - projekty stanowiące alternatywne dla dotychczasowych sposoby zwalczania wybranych problemów.

Grupa pierwsza skoncentrowała się na odczuwanym przez mieszkańców konflikcie pokoleń, wandalizmie i izolacji w stosunku do pozostałych części Radlina, a zaproponowane rozwiązanie nazwano „Swój do swego”. Projekt dotyczył aktywizacji i integracji mieszkańców Kolonii Emma. Jego celem był tak zwany wolontariat podwórkowy. Projektanci wspólnie z mieszkańcami przyjęli założenie, że każdy - niezależnie od wykształcenia i wieku - ma do zaoferowania pewne umiejętności lub wolny czas, którymi może bezinteresownie podzielić się z innymi. Ideą jest tutaj współpraca, nawiązywanie kontaktów i wzajemne niesienie pomocy. Projekt może być realizowany na dwa sposoby: poprzez materiały drukowane oraz materiały 
umieszczone na stronie internetowej. Domy rodzin, które przystąpią do projektu, będą oznakowane specjalnym znakiem, na którym zostaną umieszczone informacje o umiejętnościach domowników. Szukać pomocy będzie można, spacerując po osiedlu lub przeglądając stronę internetową, na której będą prezentowane poszczególne osoby i ich potencjał pomocowy. Dzięki zaistnieniu w przestrzeni osiedla symboli świadczących o chęci udzielania pomocy mieszkańcy będą mniej skrępowani, częściej zwracając się o pomoc. Studenckie pomysły dzięki swojej oryginalnej formie mogą sprawić, że uda się wzbudzić zainteresowanie wśród młodych mieszkańców Kolonii Emma, którzy dotychczas najmniej angażowali się w działania tej społeczności (Gdowicz i Więckowska 2013).

Druga grupa skoncentrowała się na aspektach przestrzennych, zwracając szczególną uwagę na problemy komunikacyjne oraz brak miejsc do zabawy dla dzieci i odwołując się jednocześnie do potencjału tkwiącego w układzie ścieżek wydeptanych na obszarze osiedla. Zwrócono uwagę na niepokojące zjawisko „grodzenia” wykorzystywanych przejść, co znacznie utrudniało poruszanie się po Emmie. Projektanci zaproponowali zatem wyznaczenie najważniejszej ścieżki (trasy), co otworzyłoby szanse na nadanie nowych funkcji społecznych terenom bezpośrednio do niej przylegającym. Zarówno projektanci, jak i mieszkańcy uznali, że jeżeli nie powstrzyma się procesu grodzenia i zaniecha się jakichkolwiek prac remontowych oraz porządkowych, to utraci się nie tylko ważny element systemu komunikacji pieszej, lecz również istotną przestrzeń publiczną. Zaproponowana koncepcja - „Ścieżka Emmy i Marcela" - w założeniach rozwiązuje kilka istotnych problemów: stworzenia odpowiednich $\mathrm{i}$ integrujących miejsc dla najmłodszych, dorosłych i starszych osób; poprawy bezpieczeństwa na skrzyżowaniach ulic ze ścieżką; ulepszenia nawierzchni; podkreślenia przebiegu ścieżki, aby w przyszłości nie zaniknęła. Najistotniejszą kwestią jest jednak zapewnienie ciągłości przejścia przez osiedle (Gdowicz i Więckowska 2013).

W końcu trzecia grupa również skoncentrowała się na kwestiach społecznych. Problem, z którym uczestnicy warsztatów chcieli się zmierzyć, to konsekwencje przyszłego zamknięcia kopalni, która obecnie stanowi jeden z najważniejszych elementów otoczenia Emmy. Grupa uznała, że jest to ważne zagadnienie, gdyż brak odpowiedniego przygotowania do zmian na rynku pracy może przynieść szereg negatywnych skutków, w szczególności znaczny wzrost bezrobocia, a w konsekwencji izolację, wykluczenie i bierność. Tym razem uczestnicy warsztatów zaproponowali, aby w Emmie organizować dla mieszkańców cykliczne festyny, które uczyłyby ich podstaw przedsiębiorczości, zmieniałyby sposób postrzegania samych siebie i własnych możliwości, a jednocześnie integrowały z ludźmi z innych części Radlina. Ponadto działaniem, które w niedalekiej przyszłości zmieniłoby wizerunek dzielnicy na zewnątrz, miałoby być stworzenie biznesowej gry planszowej. Całość działań zatytułowana „Marianka-wymianka” została zaprojektowana w perspektywie długofalowej, uwzględniającej wyczerpanie się zasobów kopalni, która zasila obecną gospodarkę miasta i dzielnicy. Mając na uwadze ewentualną zmianę branży przedsiębiorstwa w przyszłości, już teraz należy podejmować działania przygotowujące społeczność do tych zmian. Jednym z pierwszych kroków, jaki należy podjąć, jest wzmocnienie poczucia wartości mieszkańców, integracja wewnątrz i na zewnątrz osiedla oraz promocja przedsiębiorczego i biznesowego sposobu myślenia (Gdowicz i Więckowska 2013: 67-75). 


\section{BODZIEC DO DZIAŁANIA}

Zgodnie z ideą i przyjętymi założeniami warsztatów „Design w terenie!” opracowane koncepcje pozostają własnością lokalnej społeczności. To jej członkowie podejmować mają decyzje o ich dalszym wykorzystaniu w przyszłości. Potencjalne realizacje zaproponowanych rozwiązań będą wymagać oczywiście znacznych wysiłków od wszystkich zainteresowanych stron. Wykonanie projektu infrastrukturalnego wiąże się z mediacjami pomiędzy właścicielami nieruchomości, gdyż ingeruje w podział własnościowy terenu. Władza samorządowa może moderować te negocjacje, jednak powodzenie całego procesu jest zagrożone przez widoczną w przestrzeni tendencję do grodzenia działek prywatnych. Wdrożenie pomysłów, których celem jest integracja i wzmocnienie kompetencji społeczności Emmy, jest jedynie z pozoru łatwiejsze. Świadome wprowadzanie zmiany społecznej oparte powinno być na szerokim partnerstwie różnych interesariuszy, dostosowanym do lokalnych uwarunkowań i potrzeb. Należy przy tym podkreślić, że zapewnienie trwałości zmiany społecznej, którą mogą zainicjować lub wspomóc, zaproponowane przez uczestników warsztatów pomysły, wymaga myślenia w sposób strategiczny i konsekwentny. Aktywności te nie mogą być jednorazowe czy oddzielone od innych wydarzeń i działań (Jaworski 2013).

Podejmując próbę refleksyjnego spojrzenia na opisaną inicjatywę, cenne wydaje się odwołanie do wypowiedzi jednego z uczestników projektu - mieszkańca Emmy, który przyglądając się wypracowanym rozwiązaniom, skwitował: „ten projekt otworzył nasze głowy”. Wydaje się, że opracowany scenariusz działania przyczynił się do zwiększenia poziomu świadomości każdej z uczestniczących w nim grup.

W przypadku zaangażowanych studentów, przyszłych adeptów sztuki projektowej, dał szanse na poznanie specyfiki współpracy z realnym odbiorcą - użytkownikiem wytworów ich pracy. I chociaż filozofią współczesnego projektowania jest uniwersalność, to jednak jego zastosowanie powinno być regionalne lub nawet lokalne. Dlatego opracowane koncepcje projektowe skierowane były do konkretnej społeczności, mieszkańców konkretnej ulicy i grupy osób.

Również lokalni włodarze przekonać się mogli o skuteczności niestandardowych działań służących rozwiązaniu konkretnych problemów. Wychodzenie poza przyjęty schemat sposobów aktywizacji społecznej mieszkańców okazało się szansą na rzeczywiste pobudzenie lokalnego potencjału.

Mieszkańców można określić jak beneficjentów nie tylko wypracowanych projektów, ale również świadomości własnej siły i możliwości. Nie chodzi tutaj oczywiście o patetyczną nadinterpretację skutków opisanego przedsięwzięcia. Trudno jednak nie zgodzić się ze stwierdzeniem, że podobne inicjatywy stanowić mogą istotny bodziec do działania i niepodważalny dowód na drzemiące w społecznościach lokalnych kapitały. Ich umiejętne wykorzystanie przez angażowanie i rzeczywistą permanentną partycypację tych społeczności determinuje bowiem powstawanie rozwiązań wpisujących się bezpośrednio w indywidualne i zbiorowe potrzeby, których nosiciele odgrywają podwójną rolę - kreatorów i beneficjentów - opracowywanych rozwiązań. 


\section{BIBLIOGRAFIA}

Carmona, Metthew, Steve Tiesdell, Tom Heath i Oc Taner. 2010. Public places public spaces: The dimensions of urban design, London: Architectural Press.

Citizens as Partners, OECD Handbook on Information, Consultation and Public Participation in Policy-making, OECD 2001, www.oecdbookshop.org.

Dymnicka, Małgorzata i Tomasz Rozwadowski. 2009. Wokót idei dobrego miasta, w: Małgorzata Dymnicka, Andrzej Majer (red.), Współczesne miasta. Szkice socjologiczne, Łódź: Wydawnictwo Uniwersytetu Łódzkiego, Polskie Towarzystwo Socjologiczne.

Dymnicka, Małgorzata. 2013. Przestrzeń publiczna a przemiany miasta, Warszawa: Wydawnictwo Naukowe Scholar.

Frysztacki, Krzysztof. 2005. Między przestrzenia i publicznościa miejska, w: Bohdan Jałowiecki, Andrzej Majer i Marek Stanisław Szczepański (red.), Przemiany miasta. Wokót socjologii Aleksandra Wallisa, Warszawa: Wydawnictwo Naukowe Scholar.

Gawron, Grzegorz i Paulina Rojek-Adamek. 2012a. Miejski design na Ślasku - samorzqdy i projektanci $w$ kreowaniu wizerunku ślaskich miast, w: Krzysztof Malicki (red.), Marka i promocja jednostek terytorialnych. Dylematy i wyzwania współczesności, Rzeszów: Wydawnictwo Uniwersytetu Rzeszowskiego.

Gawron, Grzegorz i Paulina Rojek-Adamek. 2012b. Rewitalizacja na hałdzie, czyli ślaski pejzaż poprzemysłowy, w: Krzysztof Derejski, Jacek Kubera, Stanisław Lisiecki i Roman Macyra (red.): Deklinacja odnowy miast. Z dyskusji nad rewitalizacja w Polsce, Poznań: Wydawnictwo Uniwersytetu im. Adama Mickiewicza.

Gdowicz, Wiesław i Marta Więckowska (red.). 2013. Radlin - design w terenie. Katowice: Urząd Marszałkowski Województwa Śląskiego, Akademia Sztuk Pięknych w Katowicach.

Gehl, Jan. 2001. Life Between Buildings: Using Public Space, Kopenhaga: The Danish Architectural Press.

Golędzinowska, Anna. 2010. Strategie tworzenia dobrej przestrzeni publicznej w matych i średnich miastach, w: Piotr Lorens i Justyna Martyniuk-Pęczak (red.), Problemy ksztattowania przestrzeni publicznych, Gdańsk: Wydawnictwo Urbanista.

Hałat, Paweł. 2010. Instruments of social participation in the local revitalisation programmes w: Aleksander Noworól i Krzysztof Skalski (red.), Contemporary understanding of revitalization in Poland of the cities in Poland, Kraków: Uniwersytet Jagielloński.

Hausner, Jerzy. 1999. Poradnik, komunikacja i partycypacja, Kraków: Małopolska Szkoła Administracji Publicznej Akademii Ekonomicznej w Krakowie.

Jak przetworzyć miejsce. Przewodnik kreowania udanych przestrzeni publicznych. 2013. Kraków: Project for Public Spaces, Inc. Fundacja Partnerstwo dla Środowiska.

Jałowiecki, Bohdan i Marek Stanisław Szczepański. 2005. Miasto i przestrzeń w perspektywie socjologicznej, Warszawa: Wydawnictwo Naukowe Scholar.

Jaworski, Paweł. 2013. Odpowiedzialność za przestrzeń publiczna, w: Wiesław Gdowicz i Marta Więckowska (red.), Radlin - design w terenie. Katowice: Urząd Marszałkowski Województwa Śląskiego, Akademia Sztuk Pięknych w Katowicach.

Kochanowski, Mieczysław. 2002. Niepokoje i pytania, w: Mieczysław Kochanowski (red.), Przestrzeń publiczna miasta postindustrialnego, Gdańsk: Wydawnictwo Politechniki Gdańskiej. 
Kosiński, Wojciech. 2013. Wstęp do wydania polskiego, w: Jak przetworzyć Miejsce. Podręcznik kreowania udanych przestrzeni publicznych. Project for Public Spaces, Inc. Kraków: Fundacja Partnerstwo dla Środowiska.

Kożuch, Barbara. 2003. Zarzqdzanie publiczne w zarysie, Białystok: Fundacja Współczesne Zarządzanie.

Lockwood, Thomas. 2010. Między biznesem a klientem, www.pro-design.com.pl.

Lorens, Piotr. 2005. Tematyzacja przestrzeni publicznej miasta, w: Bohdan Jałowiecki, Andrzej Majer i Marek Stanisław Szczepański (red.), Przemiany miasta. Wokół socjologii Aleksandra Wallisa, Warszawa: Wydawnictwo Naukowe Scholar.

Lorens, Piotr. 2010a. Główne typy i rodzaje współczesnych przestrzeni publicznych, w: Piotr Lorens i Justyna Martyniuk-Pęczak (red.), Problemy ksztattowania przestrzeni publicznych, Gdańsk: Wydawnictwo Urbanista.

Lorens, Piotr. 2010b. Definiowanie wspótczesnej przestrzeni publicznej, w: Piotr Lorens i Justyna Martyniuk-Pęczak (red.), Problemy kształtowania przestrzeni publicznych, Gdańsk: Wydawnictwo Urbanista.

Markowski, Tadeusz. 1999. Zarzadzanie rozwojem miast, Warszawa: Wydawnictwo PWN.

Markowski, Tadeusz. 2006. Marketing terytorialny, Warszawa: Komitet Przestrzennego Zagospodarowania Kraju PAN.

Pilch, Jerzy. 2004. Europejski Fundusz Społeczny a programy rewitalizacji miasta, w: Lucyna Frąckiewicz (red.), Wykluczenie, rewitalizacja, spójność społeczna, Katowice - Warszawa: Wydawnictwo Śląsk.

Paweł, Jaworski. 2013. Kontynuacja, w: Wiesław Gdowicz i Marta Więckowska (red.), Radlin - design w terenie, Katowice: Urząd Marszałkowski Województwa Śląskiego, Akademia Sztuk Pięknych w Katowicach.

Rasouli, Mojgan. 2013. Analysis of Activity Patterns and Design Features Relationships in Urban Public Spaces Using Direct Field observations, Activity Maps and GIS Analysis Mel Lastman Square in Toronto as a Case Study. Ontario, https:/uwspace.uwaterloo.ca/ bitstream/handle/10012/7383/Rasouli_Mojgan.pdf;jsessionid=B7804A252233BF95348 FE7DF85612B7B?sequence=1 [15.03.2015].

Ruczyński, Roman. 2010. Tradycyjna urbanistyka a współczesne realizacje przestrzeni publicznych, w: Piotr Lorens i Justyna Martyniuk-Pęczak (red.), Problemy ksztattowania przestrzeni publicznych, Gdańsk: Wydawnictwo Urbanista.

Wallis, Aleksander. 1979. Informacja i gwar. O miejskim centrum, Warszawa: Państwowy Instytut Wydawniczy.

Varna, Georgiana Mihaela. 2010. Assessing the Publicness of Public Space: The Star Model of Publicness, ,Journal of Urban Design, 11: 575-598.

Zuziak, Zbigniew. 2002. Nowe przestrzenie podróży. Przestrzenie publiczne węzłów transportu, w: Mieczysław Kochanowski (red.), Przestrzeń publiczna miasta postindustrialnego, Gdańsk: Wydawnictwo Politechniki Gdańskiej.

\section{STRONY INTERNETOWE:}

http://www.pro-design.com.pl

http://www.design-silesia.pl 


\section{“DESIGN IN THE FIELD”- PARTICIPATION OF LOCAL COMMUNITIES} IN THE PROCESS OF REVITALIZATION.

Many Silesian cities and their districts still has strong traces of the industrial past, which often show their spatial and social degradation. This industrial inheritance and difficult process of restructuring has set a serious challenge for local governments. The answer for it is the search for new solutions and scenarios which should have introduced a new quality of life and functioning of the local community. One of the interesting projects in this area were design workshops "Design in the field". Their uniqueness was based on the combined creative potential of designers and residents of selected cities to find a new solutions to meet local needs and problems.

Keywords: local community, public space, participation, revitalization, design 